\title{
ENDOGENOUS PRODUCT VERSUS PROCESS INNOVATION AND A FIRM'S PROPENSITY TO EXPORT
}

\author{
SASCHA O. BECKER \\ PETER H. EGGER
}

CESIFO WORKING PAPER No. 1906

CATEGORY 9: INDUSTRIAL ORGANISATION

FEBRUARY 2007

An electronic version of the paper may be downloaded

- from the SSRN website:

- from the RePEc website:

www.SSRN.com

- from the CESifo website: 


\title{
ENDOGENOUS PRODUCT VERSUS PROCESS INNOVATION AND A FIRM'S PROPENSITY TO EXPORT
}

\begin{abstract}
This paper provides an empirical analysis of the effects of new product versus process innovations on export propensity at the firm level. Product innovation is a key factor for successful market entry in models of creative destruction and Schumpeterian growth. Process innovation helps securing a firm's market position given the characteristics of its product supply. Both modes of innovation are expected to raise a firm's propensity to export. According to new trade theory, we conjecture that product innovation is relatively more important in that regard. We investigate these hypotheses in a rich survey panel data set with information about new innovations of either type. With a set of indicators regarding innovation motives and impediments and continuous variables at the firm and industry level at hand, we may determine the probability of launching new innovations and their impact on export propensity at the firm level through a double treatment approach.
\end{abstract}

JEL Code: F1, O3, L1.

Keywords: product innovation, process innovation, propensity to export, multiple treatment effects estimation.

Sascha O. Becker

Center for Economic Studies and CESifo at the University of Munich

Schackstr. 4

80539 Munich

Germany

sbecker@lmu.de
Peter Egger

Ifo Institute for Economic Research

at the University of Munich

Poschingerstr. 5

81679 Munich

Germany

egger@ifo.de

December 4, 2006

We would like to thank the participants at the workshop Globalization Effects on Firms and Workers at the University of Nottingham, November 2006, for comments on an earlier draft. In particular, we are indebted in Zhihong Yu for helpful suggestions. 


\section{Introduction}

Research on the role of innovation on economic outcome has for long been at the heart of three different fields of the profession: macro-economics, international economics, and industrial economics. Two central assumptions can be thought of unifying these literatures, namely that innovation is endogenous at the firm-level, and it is undertaken for the sake of distinguishing products from competitors (horizontally or qualitatively) thereby securing a firm's market position against its rivals. We may associate innovation of that kind with what we will refer to as product innovation. While macro and trade economics tend to think of firm-level productivity as being determined by nature or even drawn from a lottery, there is a well-established literature in industrial organization that suggests that endogenous productivity gains are possible through process innovation.

Overall, product characteristics and high productivity are now understood as the corner stones for firms to sustain competition on the domestic but even more so on global markets. Accordingly, we hypothesize that there is a distinct role to play for product and and process innovations. Yet, their distinct impact on domestic and foreign market penetration is hitherto the target of only small bodies of theoretical and empirical work. To a large extent, product and/or process characteristics and the corresponding modes of innovation are typically viewed to be beyond a firm's choice. The latter is, however, largely at odds with both economic intuition and stylized facts.

This paper aims at contributing to previous empirical work on innovation and exports by distinguishing between the effects of product and process innovation on firm-level export propensity, and, at the same time, by taking full account of either kind of innovation's endogeneity.

The remainder of the paper is organized as follows. The next section provides an overview of earlier theoretical and empirical work on innovation to motivate determinants of innovations and derive hypotheses about their consequences for productivity and export propensity. Section 3 elaborates on the empirical framework for estimating the impact of two endogenous modes of innovation on export propensity. Section 4 summarizes the main features of our survey data. The empirical findings are presented in Section 5, they are discussed and their sensitivity is investigated in Section 6, and the last section concludes with a summary of the central findings. 


\section{Previous research and the contribution of this paper}

In the subsequent discussion of previous, innovation-related economic work, it is useful to distinguish between theoretical and empirical research on the issue.

\subsection{Economic theory on innovation}

There is a sizeable body of theoretical work that elaborates on the determinants of innovation and their consequences for productivity and economic growth and, to a lesser extent, for exports.

Macro-economists stress the importance of innovation in new products as a prerequisite for economic growth. As indicated before, innovation is endogenous itself and firms innovate more likely in large economies (where fixed costs can be covered more easily), if the (exogenous) productivity in research labs is high, product markets are competitive, and if consumers value a large variety and/or a high quality of available products (see Grossman and Helpman, 1991, chapters 3 and 4). Implicitly, most of the related studies confine their interest to product innovation. Only recently, macro-economists explore the potential differences between product and process innovations for income, focusing on heterogeneous agents and technological unemployment (Foellmi and Zweimüller, 2005). One key finding in the latter branch of work is that process innovation may lead to technological unemployment in the short-to-medium run which may be offset by product innovation in the long-run. While both process and product innovation spur aggregate income, product innovation is preferable by avoiding the adverse effects of technological unemployment.

International economic theory spots the role of product innovation for trade in open economy growth models (Dollar, 1986; Jensen and Thursby, 1987; Grossman and Helpman, 1989, 1990, 1991, chapters 9-11; Segerstrom, Anant, and Dinopoulos, 1990). As in closed-economy models of endogenous growth, market size, the productivity of research labs, consumer preferences favoring a larger variety and/or a higher quality of products, and product market competition are key determinants of innovation. An economy's openness to trade additionally fosters product market competition and, hence, creates an incentive for a firm to innovate. In turn, innovation is a prereq- 
uisite for firms to gain access to foreign consumer bases via exports. The latter establishes the hypothesis of innovation-driven exports. In recent dynamic models with firms that exhibit heterogeneous productivity levels and, hence, heterogeneous marginal production costs (Jovanovich, 1982; Hopenhayn, 1992; Melitz, 2003; Grossman, Helpman, and Szeidl, 2006) investment in firm-specific assets leads to a selection of firms: the least productive ones do not participate at the market at all and the most productive ones supply consumers not only at home but also abroad (through exports), while those with an intermediate productivity only face demand from domestic consumers. There, investment in firm-specific assets (to be associated with product innovation, see Spence, 1984) and a high corresponding outcome (i.e., a high total factor productivity) are the key determinants of a firm's export propensity.

Research in industrial economics provided pioneering results on the role of marginal cost-reducing innovations (i.e., expenditures for research and development for the sake of process innovation) in international oligopoly models more than two decades ago (Spencer and Brander, 1983). A higher investment in such process innovations increases a firm's domestic and foreign output. However, this eventually leads to an excessive amount of innovations of that kind. The equilibrium level of (process) innovation expenditures increases with domestic and foreign market size, and it declines in the level of trade costs and the degree of product market competition (i.e., the number of competitors in the market). Subsequent research established insights in the relationship between process innovation and competitive pressure at the local (Martin, 1993) and the global level (Baily and Gersbach, 1995). More recently, an explicit treatment of product versus process innovations and the role of competitive pressure has been delivered by Boone (2000). The impact of product market competition on a firm's product and process innovations crucially depends on the firm's efficiency relative to its competitors. When assuming that the aggregate efficiency can be measured by the (inverse of) average production costs, then, Boone's (2000) analysis suggests that a higher level of competitive pressure cannot increase product and process innovation at the same time. Rather, an increase in the competitive pressure may increase the efficiency of each surviving firm but lead to the exit of less productive ones, which is associated with a decline in product innovation. Overall, a positive impact of competitive pressure on process innovation is a possible, yet not a necessary outcome. 


\subsection{Empirical work on the determinants and effects of innovation}

Numerous previous empirical studies point to a positive impact of innovation on exports at the firm- or plant-level. Some of the related studies rely on R\&D expenditures as an indirect measure of innovations (Hirsch and Bijaoui, 1985; Kumar and Siddharthan, 1994; Braunerhjelm, 1996; Basile, 2001) and a smaller number of studies employs survey data with explicit information on the actual innovations (Wakelin, 1998; Bernard and Jensen, 1999; Roper and Love, 2002; Cassiman and Martínez-Ros, 2004; Lachenmaier and Wößmann, 2006). Overall, these studies point to a strong positive impact of innovations on exports. ${ }^{1}$ While most of the mentioned studies were carried out in crosssectional data-sets, there is evidence of a positive impact of innovation on exports (or export growth) also in panel data-sets (Hirsch and Bijaoui, 1985; Cassiman and Martínez-Ros, 2004).

Surprisingly, in as much as the aforementioned theoretical models establish an endogenous determination of innovations, and economic theory on innovation and exports addresses their simultaneous determination (Hughes, 1998), empirical micro-econometric work on innovation-driven exports tends to model the selection of firms into innovations as a random (or exogenous) process. Two exceptions in the latter regard are Cassiman and MartínezRos (2004) and Lachenmaier and Wößmann (2006). Both studies exploit information from panel data. Cassiman and Martínez-Ros (2004) focus on innovations as such and treat them as predetermined variables (hence, they use once-lagged instead of contemporaneous innovations in the export regressions). Lachenmaier and Wößmann (2006) apply instrumental-variable procedures to account for the potential endogeneity of innovations. One of their major findings is that innovations are indeed endogenous and their exogenous treatment leads to largely downward-biased estimates of the impact of innovations on firm-level exports.

\subsection{Contribution of this paper}

This paper departs from the strategy adopted in previous micro-econometric work on the innovation-driven exports hypothesis in two important ways.

\footnotetext{
${ }^{1} \mathrm{~A}$ smaller number of studies that employed the less preferable $\mathrm{R} \& \mathrm{D}$ expenditures as an indirect measure of innovations lacked to find such a positive impact (see Cassiman and Martínez-Ros, 2004, for a survey).
} 
First, it explicitly distinguishes between product and process innovations in the analysis and, second, it accounts for their endogeneity by allowing for an endogenous selection of firms into product and process innovations. ${ }^{2}$ In contrast to earlier work, we use matching techniques for multiple binary treatments - in our case, new product and/or process innovations versus no innovations at all - to account for self-selection of firms into either type of innovation.

\section{Empirical framework}

In the subsequent analysis we assume that, after controlling for a set of observable variables, treatment participation does not depend on treatment outcome. The latter is also referred to as the assumption of conditional mean-independence (see Wooldridge, 2002). One strategy of exploiting this assumption for the purpose of treatment effect identification is propensity score matching (see Angrist, 1998; Dehejia and Wahba, 1999, 2002; Heckman, Ichimura, and Todd, 1997, 1998; Lechner, 2001; Heckman, LaLonde, and Smith, 1999, provide a survey).

Since our data set allows us to disentangle product innovation from process innovation - hence, there are two treatment indicators at the firm level -, we have to depart from the strategy typically applied in models with a simple binary treatment variable. Obviously, the choice set from a firm's perspective can not be captured by a single binary indicator, but rather it spans a $2 \times 2$ matrix of mutually exclusive innovation-related treatments. Let us use superscripts $0, d$, and $c$ to indicate the cases of no treatment, product

\footnotetext{
${ }^{2}$ Cohen and Klepper (1996) formulate and test a model of the determinants of product as well as process innovation in a cross-sectional data-set of 587 U.S. firms. They find that large firms, in accordance with their model, have a greater incentive to pursue both process and product innovations. However, these firms face a relatively larger incentive to undertake process and more incremental innovations as compared to small ones. MartínezRos (2000) provides an empirical analysis of the determinants of product and process innovations in a Spanish firm-level data-set. Neither of these studies considers the impact of these two modes of endogenous innovations on exports. Basile (2001) looks at the effect of product and process innovations (measured by two different R\&D expenditure modes) on exports, but he treats innovations as exogenous. The paper by Lachenmaier and Wößmann (2006) also distinguishes between product and process innovations, but only in one of the specifications in the sensitivity analysis. There, neither the impact of product innovations nor that one of process innovations on exports is significantly different from zero.
} 
innovation, and process innovation, respectively. Then, the four mutually exclusive treatments are $(0,0)$ (the no treatment case), $(d, 0)$ (new product innovations only), $(0, c)$ (new process innovations only), and $(d, c)$ (both new product and new process innovations). ${ }^{3}$ A matching approach with multiple treatments has been derived by Lechner (2001). ${ }^{4}$

For convenience, let us refer to the no treatment outcome as $Y^{(0,0)}$ (i.e., the corresponding export propensity as captured by a binary firm-level export indicator). The remaining possible outcomes are $Y^{(d, 0)}, Y^{(0, c)}$, and $Y^{(d, c)}$, respectively. Let us use superscripts $m$ and $l$ as running indices for the four treatments to determine three different types of treatment effects (see Lechner, 2001). The expected average effect of treatment $m$ relative to treatment $l$ for a firm drawn randomly from the population is defined as

$$
\gamma^{m, l}=E\left(Y^{m}-Y^{l}\right)=E\left(Y^{m}\right)-E\left(Y^{l}\right) .
$$

The expected average effect of treatment $m$ relative to treatment $l$ for a firm randomly selected from the group of firms participating in either $m$ or $l$ is defined as

$$
\alpha^{m, l}=E\left(Y^{m}-Y^{l} \mid S=m, l\right)=E\left(Y^{m} \mid S=m, l\right)-E\left(Y^{l} \mid S=m, l\right),
$$

where $S$ is the assignment indicator, defining whether a firm receives treatment $m$ or $l$. Finally, the expected average effect of treatment $m$ relative to treatment $l$ for a unit that is randomly selected from the group of firms participating in $m$ only is defined as

$$
\theta^{m, l}=E\left(Y^{m}-Y^{l} \mid S=m\right)=E\left(Y^{m} \mid S=m\right)-E\left(Y^{l} \mid S=m\right) .
$$

Note that both $\gamma^{m, l}$ and $\alpha^{m, l}$ are symmetric in the sense that $\gamma^{m, l}=-\gamma^{l, m}$ and $\alpha^{m, l}=-\alpha^{l, m}$, whereas $\theta^{m, l}$ is not, so that $\theta^{m, l} \neq-\theta^{l, m}$.

Estimates of the average treatment effects can be obtained as follows. First, the response probabilities for each treatment can be estimated either by a bivariate probability model (it is customary to use a logit or a probit model). Denote the estimated response probabilities that are a function of the vector

\footnotetext{
${ }^{3}$ Notice that the underlying choices are unordered, here.

${ }^{4}$ See also Lee (2005) for a recent discussion of this framework.
} 
of observable variables $\mathbf{x}$ as $\hat{P}^{m}(\mathbf{x})$ for $m=(0,0) ;(d, 0) ;(0, c) ;(d, c)$, respectively. Second, estimate the expectation $E\left(Y^{m} \mid S=m\right)$ by $E\left\{E\left[Y^{m} \mid \hat{P}^{m}(\mathbf{x}) S=\right.\right.$ $m] \mid S \neq m\}$ and the expectation $E\left(Y^{l} \mid S=m\right)$ by $E\left\{E\left[Y^{l} \mid \hat{P}^{l}(\mathbf{x}), \hat{P}^{m}(\mathbf{x}) S=\right.\right.$ $l] \mid S=m\}$. We apply radius matching (each treated firm is compared to all firms within a certain radius around its propensity score), nearest-neighbor matching (each treated firm is compared to a single control unit), and kernel matching (each treated unit is compared to all untreated firms in a certain area around the propensity score depending on the bandwidth of the kernel, but inversely weighted with their difference in propensity score to the treated unit). The average treatment effect (i.e., the outer expectation above) is estimated as the average of the difference in outcomes between the treated and the control units.

We pursue two alternative estimates of the standard error of each of the treatment effects. First, we compute analytic standard errors as in Lechner (2001). The analytic standard errors for the three treatment effect concepts are

$$
\begin{aligned}
\operatorname{Var}\left(\hat{\theta}^{m, l}\right) & =\frac{1}{N^{m}} \operatorname{Var}\left(Y^{m} \mid S=m\right)+\frac{\sum_{i \in l}\left(w_{i}^{m}\right)^{2}}{\left(\sum_{i \in l} w_{i}^{m}\right)^{2}} \operatorname{Var}\left(Y^{l} \mid S=l\right), \\
\operatorname{Var}\left(\hat{\alpha}^{m, l}\right) & =\sum_{i \in m}\left[\frac{1+w_{i}^{l}}{N^{m}+N^{l}}\right]^{2} \operatorname{Var}\left(Y^{m} \mid S=m\right) \\
& +\sum_{i \in l}\left[\frac{1+w_{i}^{m}}{N^{m}+N^{l}}\right]^{2} \operatorname{Var}\left(Y^{l} \mid S=l\right), \\
\operatorname{Var}\left(\hat{\gamma}^{m, l}\right) & =\sum_{i \in m}\left[\sum_{j=0}^{M} \frac{w_{i}^{j}}{n}\right]^{2} \operatorname{Var}\left(Y^{m} \mid S=m\right) \\
& +\sum_{i \in l}\left[\sum_{j=0}^{M} \frac{w_{i}^{j}}{n}\right]^{2} \operatorname{Var}\left(Y^{l} \mid S=l\right) .
\end{aligned}
$$

In empirical applications, these analytical standard errors may deviate considerably from their small-sample-counterparts. Therefore, we alternatively compute sub-sampling-based standard errors following Politis, Romano, and Wolf (1999). As shown by Abadie and Imbens (2006) these give reliable variance estimates of treatment effects even in small samples. 


\section{Data}

Our data are based on the Ifo Innovation Survey that is conducted annually by the Ifo Institute, covering more than 1,000 firms in Germany per year. The survey asks about the structure of innovations at the firm level. In particular, it collects information about process versus product innovation activities and about export status. Furthermore, the survey explicitly covers questions relating to exogenous innovation impulses and obstacles as well as other firm-level characteristics. Beyond that, there is an industry indicator that allows us to link industry characteristics to the micro-level data.

\subsection{Dependent variables}

Regarding the dependent variables, the database provides information on whether a firm has exported and applied new product innovations or process innovations over the last six months or not. The corresponding questions that we rely on in our analysis can be translated as follows:

- We did not export (in year $t$ ). As our outcome variable, we construct a dummy variable that takes a value of one if firms export and zero if they do not.

- In the year $t$ we have introduced (or started but not yet finished) new product innovations. In the year $t$ we have introduced (or started but not yet finished) new process innovations. We use the answers to these questions to construct two dummy variables, one that takes on a value if new product innovations were undertaken in year $t$ and zero else, and the other is constructed in the same way but for process innovations.

Overall, there are 1,537 firms and 4,499 observations in our database. Note that every observation covers three years of data because our outcome is measured in $t+1$, the treatment in $t$ and pre-treatment variables in $t-1$. A cross-tabulation for export propensity and the two innovation indicators is provided in Table 1. The entries can be summarized as follows. First, 80.00 percent of the firms in our sample conduct exports. The high fraction of exporters is not surprising, since, by design, the survey covers mainly large manufacturing firms. Second, 61.96 percent of the firms innovate (i.e., they receive treatments $(d, 0),(0, c)$, or $(d, c))$. Of those, 23.57 percent conduct 
Table 1: Exports And InNOVATions: A SUMmary

\begin{tabular}{|c|c|c|c|}
\hline \multirow[b]{2}{*}{ Treatment } & \multicolumn{2}{|c|}{ Export } & \multirow[b]{2}{*}{ Total } \\
\hline & 0 & 1 & \\
\hline \multirow[t]{2}{*}{$\overline{(0,0)}$} & 556 & 1,155 & 1,711 \\
\hline & 32.50 & 67.50 & 100.00 \\
\hline \multirow[t]{2}{*}{$(0, c)$} & 82 & 167 & 249 \\
\hline & 32.93 & 67.07 & 100.00 \\
\hline \multirow[t]{2}{*}{$(d, 0)$} & 105 & 552 & 657 \\
\hline & 15.98 & 84.02 & 100.00 \\
\hline \multirow[t]{2}{*}{$(d, c)$} & 157 & 1,725 & 1,882 \\
\hline & 8.34 & 91.66 & 100.00 \\
\hline \multirow[t]{2}{*}{ Total } & 900 & 3,599 & 4,499 \\
\hline & 20.00 & 80.00 & 100.00 \\
\hline
\end{tabular}

Source: Ifo Innovation Survey, 1994-2004.

Possible treatments are as follows: $(0,0)$ (the no treatment case), $(d, 0)$ (new product innovations only), $(0, c)$ (new process innovations only), and $(d, c)$ (both new product and new process innovations).

product innovations only $(d, 0), 8.93$ percent conduct process innovations only $(0, c)$, and 67.50 percent do both $(d, c)$.

\subsection{Independent variables}

Beyond the information for the dependent variables in our analysis, the survey asks about a set of incentives/impulses and obstables/impediments to innovation. Of those, in our empirical model, only the following four impediments exert a significant impact on a firm's probability to innovate: lacking own capital; lacking external capital; long amortization period; imperfect opportunities to cooperate with public or academic institutions. For these obstacles to innovation, multiple answers are possible and they are numerical: 1 (not important at all); 2 (not very important); 3 (important); 4 (extremely important). We generate a binary variable for each impediment and classify 
3 and 4 as one and 1 and 2 as zero.

Furthermore, we include lagged logarithms of sales and employment at the firm level as two separate regressors. In addition to these firm-level determinants we use characteristics that vary across NACE 2-digit industries published by EUROSTAT (NewCronos Database). In particular, we employ the once lagged German real value added in nominal Euros (to capture the size of an industry), real value added per worker (to capture industry productivity), and unit labor costs (to capture wage costs per unit of output). Furthermore, we use inverse-distance weighted values of these variables for the EU14 economies (excluding Germany). There, each industrylevel explanatory variable $x_{i j t}$ for industry $i$ and time $t$ is weighted across the $14 \mathrm{EU}$ member countries as of 1995 excluding Germany according to $\tilde{x}_{i t}=\sum_{j}^{14}\left[\left(x_{i j t} d_{j} / \sum_{j} d_{j}\right]\right.$ with $d_{j}$ denoting an economy $j$ 's inverse distance to Germany. ${ }^{5}$ The industry-level variables control for both a firm's competitive pressure at the domestic and the Western European foreign markets. For instance, the inverse-distance weighted value added can be interpreted as a measure of the foreign potential supply. The higher the latter, the stronger we conjecture competition to be for German producers. By way of contrast, the higher the weighted foreign wage costs are relative to foreign output, the lower we expect the competitive pressure for German producers to be ceteris paribus. Table 2 summarizes mean and standard deviation of all covariates.

\section{Estimation results}

Table 3 presents the results of a multinomial logit model (assuming a logistic cumulative density function, respectively) determining a representative firm's choice of product and/or process innovation. In Table 9 in the Appendix, we report the corresponding findings based on a bivariate probit model (assuming a bivariate normal cumulative density function of the latent outcome variable).

The estimates and test statistics reported in Tables 3 and 9 suggest the following conclusions. First, the value of the log-likelihood under the bivariate probit model is -4312.14 while that one under the multinomial logit is

\footnotetext{
${ }^{5}$ The notion that trade - and, hence, foreign competition - decreases in distance (i.e., increases in inverse distance) is one of the most robust stylized facts in empirical research in international economics (see Leamer and Levinsohn, 1995).
} 
Table 2: Descriptive Statistics

mean s.d.

Firm-level variables

$\ln$ (Turnover) in $t-1$

10.100

1.972

$\ln$ (Turnover per worker) in $t-1$

5.350

1.024

Indic.: Lacking own capital

.293

.455

Indic.: Lacking external capital

.221

Indic.: Long amortization period

.331

.415

Indic.: Imperfect cooperation poss.

.150

.471

.357

Sector-level variables

for Germany

$\ln$ (Value-added) in $t-1$

9.608

.957

$\ln$ (Value-added per worker) in $t-1$

$-3.156$

.204

$\ln$ (Unit labor cost) in $t-1$

$-1.439$

.245

for EU14

$\ln$ (Value-added) in $t-1$

7.915

.812

$\ln$ (Value-added per worker) in $t-1$

$-3.000$

$\ln$ (Unit labor cost) in $t-1$

$-1.795$

.232

Source: Ifo Innovation Survey, 1994-2004.

-4241.27. Davidson and MacKinnon (2004) suggest selecting among such non-nested, non-linear probability models according to a likelihood ratio statistic based on twice the absolute difference in the corresponding loglikelihoods (LL): $L R=2\left|L L_{\text {probit }}-L L_{\text {logit }}\right|$. This test statistic is distributed as $\chi^{2}(13)$. Following this device, we find that the statistic amounts to 141.71, which is significant at the one percent level. Hence, the data are more appropriately described by the multinomial logit model, which we also use in the sequel for matching.

Furthermore, the test statistics indicate that domestic industry variables and weighted EU14 industry variables are group-wise and jointly significant at the one percent level in the model. Similarly, the included innovation impediments are jointly significant. 
To check whether propensity score matching achieves better balancing of the variables in our model, we calculate the reduction of the median absolute standardized bias in the observables included in the selection models between the treated firms and all control units versus the treated and the matched control units. While there is no firm rule of thumb, the statistics literature suggests that the remaining bias should definitely be smaller than 20 percent (Rosenbaum and Rubin, 1985). In our case, the median bias between the treated and the matched control units amounts to about 8 percent, which seems reasonable. In the case of statistically significant effects, the bias reduction is even larger. For instance, for the effect $(d, c)$ versus $(0,0)$, the median absolute standardized bias drops from 32.70 to 3.05. Overall, matching reduces the bias by about two thirds. Similarly, comparing the pseudo- $R^{2}$ of the propensity score estimation before and after matching, we find a significant drop in explanatory power. For instance, for the effect $(d, c)$ versus $(0,0)$, the pseudo- $R^{2}$ before matching is 0.354 , i.e., the covariates are relevant predictors in the overall sample. However, in the matched sample of nearest neighbors, the pseudo- $R^{2}$ of the same selection regression drops to 0.037 , i.e., in the matched sample, there is no remaining systematic difference in observables between treated and control firms. Put differently, our matching procedure does a good job in balancing firm and sector characteristics and allows us to match comparable firms as required.

Based on these findings, we can turn to estimating the various treatment effects of product and process innovations on firm-level export propensity. Here, we use a radius matching as our reference model outcome. This type of matching requires that the matched control units exhibit a propensity score that differs by not more than the radius from the propensity score of the treated unit they are matched onto. Hence, in contrast to other matching estimates such as $k$-nearest neighbor matching or kernel matching, radius matching enforces a certain matching quality depending on the size of the radius (see Smith and Todd, 2005, for a discussion). We choose a radius of 0.05 in our benchmark model. However, we consider alternative matching estimators and a smaller radius in the sensitivity analysis. The most important findings based on the chosen procedure are summarized in Table 4. 
Table 3: Product And PROCESS innOVAtions: MULTinOMiAl LOGit

\begin{tabular}{|c|c|c|c|}
\hline & $\frac{(0, c)}{(1)}$ & $\frac{(d, 0)}{(2)}$ & $\frac{(d, c)}{(3)}$ \\
\hline \multicolumn{4}{|l|}{ Firm-level variables } \\
\hline $\ln$ (Turnover) in $t-1$ & $\begin{array}{l}.334 \\
(.056)\end{array}$ & $\begin{array}{l}.353 \\
(.040)\end{array}$ & $\begin{array}{l}.790 \\
(.035)\end{array}$ \\
\hline $\ln$ (Turnover per worker) in $t-1$ & $\begin{array}{c}-.161 \\
(.094)\end{array}$ & $\begin{array}{c}-.246 \\
(.064)\end{array}$ & $\begin{array}{c}-.552 \\
(.056)\end{array}$ \\
\hline Indic.: Lacking own capital & $\begin{array}{l}1.313 \\
(.239)\end{array}$ & $\begin{array}{l}1.044 \\
(.184)\end{array}$ & $\begin{array}{l}1.062 \\
(.167)\end{array}$ \\
\hline Indic.: Lacking external capital & $\begin{array}{l}-.555 \\
(.270)\end{array}$ & $\begin{array}{l}.018 \\
(.201)\end{array}$ & $\begin{array}{c}-.333 \\
(.186)\end{array}$ \\
\hline Indic.: Long amortization period & $\begin{array}{l}1.227 \\
(.188)\end{array}$ & $\begin{array}{l}1.555 \\
(.137)\end{array}$ & $\begin{array}{l}1.838 \\
(.119)\end{array}$ \\
\hline Indic.: Imperfect cooperation poss. & $\begin{array}{l}.126 \\
(.253)\end{array}$ & $\begin{array}{l}.067 \\
(.183)\end{array}$ & $\begin{array}{l}.639 \\
(.159)\end{array}$ \\
\hline \multicolumn{4}{|l|}{ Sector-level variables } \\
\hline \multicolumn{4}{|l|}{ for Germany } \\
\hline $\ln$ (Value-added) in $t-1$ & $\begin{array}{r}-.417 \\
(.250)\end{array}$ & $\begin{array}{l}.414 \\
(.172)\end{array}$ & $\begin{array}{l}.530 \\
(.146)\end{array}$ \\
\hline $\ln$ (Value-added per worker) in $t-1$ & $\begin{array}{c}-1.905 \\
(.544)\end{array}$ & $\begin{array}{c}-2.044 \\
(.369)\end{array}$ & $\begin{array}{c}-1.434 \\
(.323)\end{array}$ \\
\hline $\ln ($ Unit labor cost) in $t-1$ & $\begin{array}{l}.050 \\
(.877)\end{array}$ & $\begin{array}{c}2.421 \\
(.622)\end{array}$ & $\begin{array}{c}2.953 \\
(.530)\end{array}$ \\
\hline \multicolumn{4}{|l|}{ for $E U 14$} \\
\hline $\ln$ (Value-added) in $t-1$ & $\begin{array}{l}.626 \\
(.345)\end{array}$ & $\begin{array}{c}-.448 \\
(.225)\end{array}$ & $\begin{array}{c}-.504 \\
(.193)\end{array}$ \\
\hline $\ln$ (Value-added per worker) in $t-1$ & $\begin{array}{l}.549 \\
(.410)\end{array}$ & $\begin{array}{l}.200 \\
(.277)\end{array}$ & $\begin{array}{l}.187 \\
(.247)\end{array}$ \\
\hline $\ln ($ Unit labor cost) in $t-1$ & $\begin{array}{l}.842 \\
(.757)\end{array}$ & $\begin{array}{l}-2.603 \\
(.539)\end{array}$ & $\begin{array}{l}-2.921 \\
(.461)\end{array}$ \\
\hline Constant & $\begin{array}{c}-8.514 \\
(1.985)\end{array}$ & $\begin{array}{c}-11.124 \\
(1.400)\end{array}$ & $\begin{array}{c}-11.696 \\
(1.180)\end{array}$ \\
\hline Number of observations & & 4499 & \\
\hline
\end{tabular}

Source: Ifo Innovation Survey, 1994-2004. 


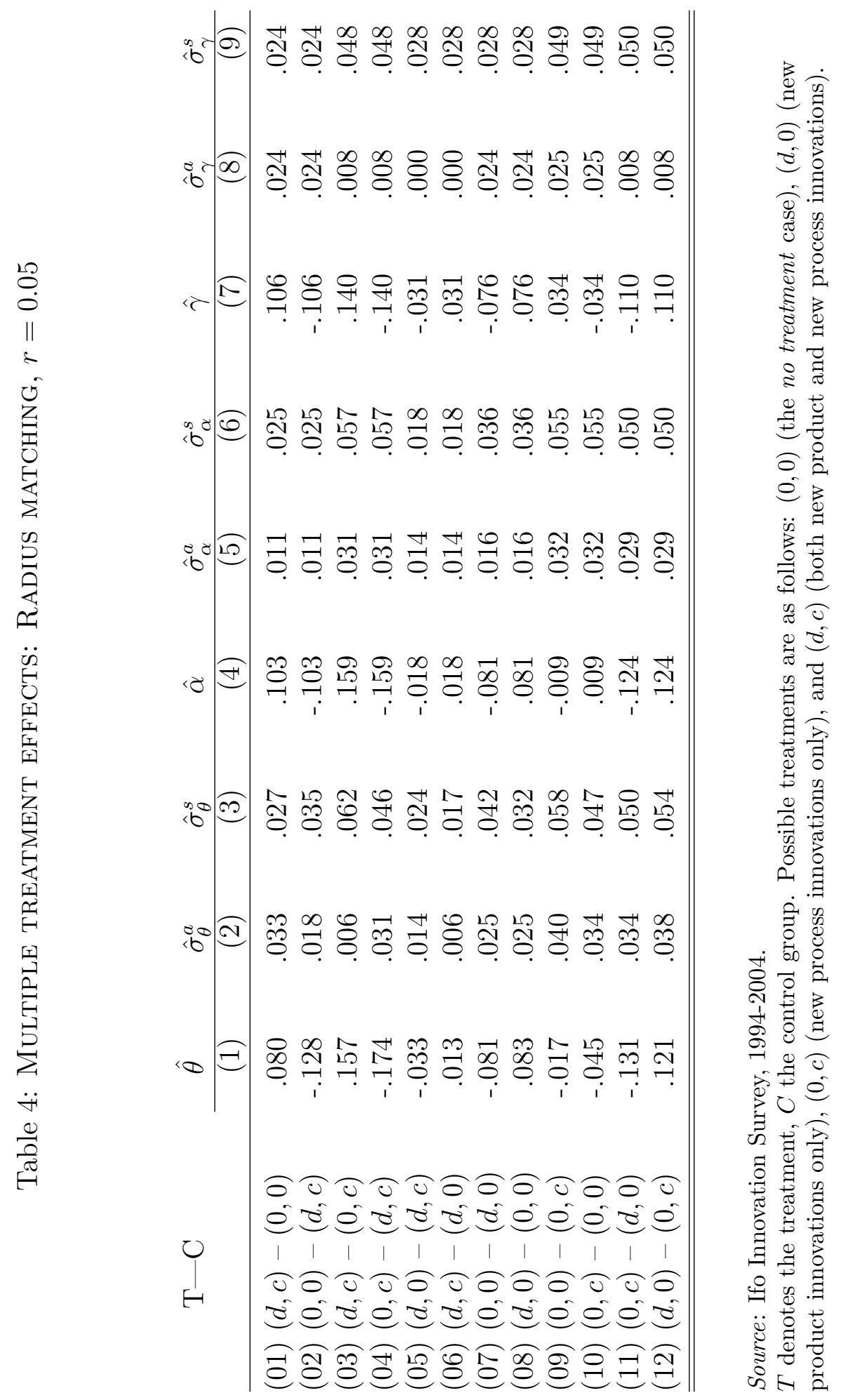


In the table, we report estimates of all three treatment effects, $\theta^{m, l}, \alpha^{m, l}$, and $\gamma^{m, l}$ for all treatment pairs $m$ and $l$ and their standard errors. In the first table column, we indicate the treatment (labeled $T$ ). For instance, $(d, c)$ refers to firms that got the treatment product and process innovation. The second column identifies the treatment of the comparison group (i.e., that for the matched control units; labeled $C$ ) in a similar way. For instance, the first row of results in the table indicates the effect of receiving the treatment $(d, c)$ as compared to the control units with treatment $(0,0)$. The other columns report the estimates for the various treatment effect concepts $(\hat{\theta}, \hat{\alpha}$, $\hat{\gamma})$, the analytical standard errors $\left(\hat{\sigma}_{\theta}^{a}, \hat{\sigma}_{\alpha}^{a}, \hat{\sigma}_{\gamma}^{a}\right)$, and their sub-sampling-based counterparts $\left(\hat{\sigma}_{\theta}^{s}, \hat{\sigma}_{\alpha}^{s}, \hat{\sigma}_{\gamma}^{s}\right) .{ }^{6}$ Our results indicate that the analytical standard errors are slightly more conservative (i.e., smaller) than the bootstrapped ones. In the subsequent discussion we will base our inference on bootstrapped rather than analytical standard errors.

Overall, the results indicate that there is a strong, positive role to play for product innovation for a firm's propensity to export. For instance, firms that conduct new product and process innovations (the treated $-T$ in the first table column - receive $(d, c)$ ) exhibit a significantly higher export propensity than ones that neither do product nor process innovations (the matched controls $-C$ in the second table column - receive $(0,0))$. The estimates suggest that firms receiving the treatment $(d, c)$ exhibit an export propensity that is about 8 percentage points higher than for those receiving the treatment $(0,0)$. Firms receiving the treatment $(0,0)$ (i.e., no innovation at all) exhibit an export propensity that is about 13 percent lower than for ones with treatment $(d, c)$. These two ATTs are significantly different from zero at conventional levels. The average treatment effect of (actually or hypothetically) receiving the treatment process and product innovation $(d, c)$, given that a firm receives either $(d, c)$ or $(0,0)$, is $\hat{\alpha} \approx 0.10$. Hence, product and process innovation together enhance a firm's export propensity by about 10 percentage points. Similar conclusions apply for the ATE: product and process innovation together increase a firm's propensity to export by about $\hat{\gamma} \approx 0.11$ - i.e., 11 percentage points -, irrespective of and unconditional on which treatment it actually received.

\footnotetext{
${ }^{6}$ We rely on the result in Abadie and Imbens (2006) that sub-sampling standard errors provide unbiased estimates of the true ones while bootstrapped standard errors do not. Here, we rely on a 1000 draws of sub-samples of size 3350 .
} 
The effect of product innovation is even stronger if a firm already engages in process innovation. This can be seen from a comparison of the point estimates in the third and fourth rows in the table where the treated $T$ receive $(d, c)$ and $(0, c)$, respectively, and the matched control units $C$ receive $(0, c)$ and $(d, c)$, respectively. These point estimates are larger in absolute values than those in the first and second lines, irrespective of whether $\hat{\theta}$, $\hat{\alpha}$, or $\hat{\gamma}$ are considered. Even switching from process to product innovation entails significant positive effects on export propensity (consider the two rows at the bottom of Table 4). While product innovations alone raise a firm's propensity to export significantly (see lines $7-8$ in the table), their impact is larger if process innovations were already realized. By way of contrast, there is no significant increase in export propensity to be expected if an already product innovating firm undertakes process innovation, in addition. Similarly, process innovations alone exert an insignificant impact on export propensity (see lines 9-10 in the table).

Is there any gain from matching in this data set? To shed light on this issue, we may compare the average treatment effect under the assumption of exogeneity of all regressors, $\left(\hat{\gamma}_{\text {exog. }}\right)$, with its endogenous counterpart as reported in Table $4(\hat{\gamma})$. The exogenous treatment effect may be thought of as the simple comparison of the average export propensity among the treated and the untreated firms for each treatment. The corresponding exogenous treatment effect estimates (i.e., the simple mean comparisons) together with their endogenous treatment effect counterparts as of Table 4 are summarized in Table 5. Since the average treatment effects are symmetric throughout, we only report every second estimate as compared to Table 4.

It seems worth noting that in one of the experiments even the sign of the exogenous treatment effect point estimate differs from the endogenous one (namely with treatment $(0, c)$ and controls $(d, 0)$, i.e., $T-C$ of $(0, c)-$ $(d, 0))$. Moreover, for five of the six parameters the (absolute) difference in the point estimates is higher than 50 percent of the endogenous treatment effect parameter. In many of these cases this difference is significant. Hence, accounting for self-selection into treatment is important in this data set, leading to significantly different average treatment effect estimates. 
Table 5: Exogenous versus endogenous multiple treatment EFFECTS

\begin{tabular}{ccccc}
$\mathrm{T}-\mathrm{C}$ & $\hat{\gamma}_{\text {exog. }}$ & $\hat{\sigma}_{\text {rexog. }}^{s}$ & $\hat{\gamma}$ & $\hat{\sigma}_{\gamma}^{s}$ \\
\cline { 2 - 5 } & $(1)$ & $(2)$ & $(3)$ & $(4)$ \\
\hline$(01)(d, c)-(0,0)$ & .233 & .018 & .106 & .033 \\
$(03)(d, c)-(0, c)$ & .091 & .020 & .140 & .065 \\
$(06)(d, c)-(d, 0)$ & .014 & .017 & .031 & .037 \\
$(08)(d, 0)-(0,0)$ & .142 & .030 & .076 & .037 \\
$(10)(0, c)-(0,0)$ & -.027 & .047 & -.034 & .066 \\
$(11)(0, c)-(d, 0)$ & .169 & .045 & -.110 & .069 \\
\hline \hline
\end{tabular}

Source: Ifo Innovation Survey, 1994-2004.

$T$ denotes the treatment, $C$ the control group. Possible treatments are as follows: $(0,0)$ (the no treatment case), $(d, 0)$ (new product innovations only), $(0, c)$ (new process innovations only), and $(d, c)$ (both new product and new process innovations). The endogenous treatment effects are repeated from Table 4.

\section{Sensitivity analysis and discussion}

We undertake several robustness checks to assess the sensitivity of our findings. In these experiments, we only report re-sampling-based standard errors of the endogenous treatment effect estimates for the sake of brevity. First, we consider an alternative radius of only 0.005 instead of 0.05 . Hence, we enforce a considerably higher precision of the matching estimates there than we did in our benchmark model in Table 4. Second, we use a nearest neighbor matching estimator, where we compare each treated firm's outcome to a single nearest neighbor, irrespective of the difference of the best match's difference in propensity score to the treated unit (i.e., the difference might be smaller or larger than than 5 or 0.05 percentage points as required with the previous radius matching estimates). Third, we use an Epanechnikov kernel-based matching with a bandwidth of 0.06 instead of the original radius matching. This kernel estimator is potentially more efficient than the radius matching estimator but it gives some weight to less comparable units than radius matching with a narrow radius does. The bandwidth determines this trade-off between efficiency and unbiasedness. Let us refer to a control unit's absolute difference to a treated firm's propensity score as $\Delta$. Then, 
only those firms with $\Delta \leq 0.06$ are given a weight of $1-(\Delta / 0.06)^{2}$ and zero else. Hence, a larger bandwidth covers more observations and gives more weight to less comparable ones. Fourth, we infer to which extent kernel matching depends on the choice of the kernel bandwidth. For this we choose a much narrower bandwidth of 0.02 which mimics (but is not identical to) the choice of a smaller radius under radius matching. Fifth, we use an alternative kernel, namely a Gaussian one with a bandwidth of 0.06. There, the kernel weight is $\phi(\Delta / 0.06)$, where $\phi(\cdot)$ is the normal density and $\Delta$ is the absolute difference in propensity scores between a treated and a control unit. Finally, we use the lagged export indicator as a determinant for innovation activities at time $t$. For instance, the latter ensures that we estimate the impact of innovation on export propensity from a comparison of treated firms with untreated ones where the export status in the past was the same between the treated and the untreated.

The results are presented in three tables. Table 6 summarizes the ATT estimates $\left(\hat{\theta}^{m, l}\right)$ for all sensitivity checks, Table 7 the estimates of $\hat{\alpha}^{m, l}$, and Table 8 those of ATE $\left(\hat{\gamma}^{m, l}\right)$. For convenience, the first column in each of these tables captures the benchmark results and is repeated from Table 4. Let us start with the ATT estimates. Across the board, neither changing the radius nor the matching estimator (nearest neighbor or alternative kernel matching estimators with different bandwidths instead of radius matching) affects our conclusions from above, neither in qualitative nor in quantitative terms.

Even considering lagged export status as a determinant of innovation mode does not change the findings in qualitative terms. However, the parameter point estimates of the treatment effects are smaller in absolute value (see column (7) in Table 6). There are two interpretations for the latter. First, inference about the corresponding estimates is based on a smaller sample as before since one year is lost when using lagged exports and only those observations can be used where the lead and lag of exports is available for a firm. Second, in this experiment we rule out any impact of innovations on future export propensity triggered by heterogeneous export status in the past. Accordingly, the matched controls are different from the ones in the original experiments. 
Table 6: Multiple treatment effects: Robustness CheCKS For $\theta$

\begin{tabular}{lrrrrrrr} 
& \multicolumn{1}{c}{$(1)$} & \multicolumn{1}{c}{$(2)$} & \multicolumn{1}{c}{$(3)$} & \multicolumn{1}{c}{$(4)$} & \multicolumn{1}{c}{$(5)$} & \multicolumn{1}{c}{$(6)$} & $(7)$ \\
\hline$(01)(d, c)-(0,0)$ & \multicolumn{1}{c}{.080} & \multicolumn{1}{c}{.077} & .085 & .079 & .073 & .075 & .043 \\
& \multicolumn{1}{c}{$.027)$} & \multicolumn{1}{c}{$.028)$} & $(.032)$ & $(.027)$ & $(.026)$ & $(.025)$ & $(.021)$ \\
$(02)(0,0)-(d, c)$ & -.128 & -.131 & -.127 & -.128 & -.129 & -.129 & -.048 \\
& $(.035)$ & $(.037)$ & $(.051)$ & $(.038)$ & $(.039)$ & $(.037)$ & $(.033)$ \\
$(03)(d, c)-(0, c)$ & .157 & .178 & .148 & .165 & .205 & .185 & .078 \\
& $(.062)$ & $(.067)$ & $(.098)$ & $(.066)$ & $(.083)$ & $(.071)$ & $(.040)$ \\
$(04)(0, c)-(d, c)$ & -.174 & -.170 & -.129 & -.174 & -.170 & -.172 & -.078 \\
& $(.046)$ & $(.052)$ & $(.062)$ & $(.046)$ & $(.048)$ & $(.047)$ & $(.036)$ \\
$(05)(d, 0)-(d, c)$ & -.033 & -.034 & -.037 & -.030 & -.032 & -.030 & -.018 \\
& $(.024)$ & $(.027)$ & $(.037)$ & $(.025)$ & $(.025)$ & $(.025)$ & $(.019)$ \\
$(06)(d, c)-(d, 0)$ & .013 & .015 & .021 & .012 & .012 & .012 & -.005 \\
& $(.017)$ & $(.020)$ & $(.024)$ & $(.017)$ & $(.018)$ & $(.017)$ & $(.011)$ \\
$(07)(0,0)-(d, 0)$ & -.081 & -.058 & -.042 & -.079 & -.067 & -.075 & -.030 \\
& $(.042)$ & $(.050)$ & $(.061)$ & $(.043)$ & $(.047)$ & $(.044)$ & $(.034)$ \\
$(08)(d, 0)-(0,0)$ & .083 & .075 & .070 & .082 & .080 & .081 & .062 \\
& $(.032)$ & $(.039)$ & $(.048)$ & $(.032)$ & $(.036)$ & $(.033)$ & $(.027)$ \\
$(09)(0,0)-(0, c)$ & -.017 & -.013 & -.060 & -.018 & -.012 & -.020 & -.059 \\
& $(.058)$ & $(.073)$ & $(.086)$ & $(.057)$ & $(.068)$ & $(.061)$ & $(.049)$ \\
& -.045 & -.045 & -.076 & -.044 & -.038 & -.041 & .010 \\
$(10)(0, c)-(0,0)$ & $(.047)$ & $(.056)$ & $(.071)$ & $(.047)$ & $(.050)$ & $(.048)$ & $(.039)$ \\
& -.131 & -.111 & -.084 & -.130 & -.125 & -.129 & -.054 \\
$(11)(0, c)-(d, 0)$ & $(.050)$ & $(.060)$ & $(.068)$ & $(.052)$ & $(.053)$ & $(.051)$ & $(.044)$ \\
& .121 & .152 & .178 & .123 & .134 & .125 & .019 \\
$(12)(d, 0)-(0, c)$ & $(.054)$ & $(.063)$ & $(.079)$ & $(.056)$ & $(.059)$ & $(.057)$ & $(.036)$ \\
& & & & & & & \\
\hline \hline
\end{tabular}

Source: Ifo Innovation Survey, 1994-2004.

$T$ denotes the treatment, $C$ the control group. Possible treatments are as follows: $(0,0)$ (the no treatment case), $(d, 0)$ (new product innovations only), $(0, c)$ (new process innovations only), and $(d, c)$ (both new product and new process innovations).

Column (1): Radius matching with $r=0.05$; Column (2): Radius matching with $r=0.005$; Column (3): Nearest neighbor matching; Column (4): Kernel matching, Epanechnikov kernel, bandwidth 0.06; Column (5): Kernel matching, Epanechnikov kernel, bandwidth 0.02; Column (6): Kernel matching, Gaussian kernel; Column (7): Radius matching, $r=0.05$, with control for past export status. 
Table 7: Multiple treatment effects: Robustness CheCKS FOR $\alpha$

\begin{tabular}{lrrrrrrr} 
& \multicolumn{1}{c}{$(1)$} & \multicolumn{1}{c}{$(2)$} & \multicolumn{1}{c}{$(3)$} & \multicolumn{1}{c}{$(4)$} & \multicolumn{1}{c}{$(5)$} & \multicolumn{1}{c}{$(6)$} & $(7)$ \\
\hline$(01)(d, c)-(0,0)$ & .103 & .103 & .105 & .102 & .100 & .101 & .046 \\
& $(.025)$ & $(.026)$ & $(.032)$ & $(.026)$ & $(.026)$ & $(.025)$ & $(.021)$ \\
$(02)(0,0)-(d, c)$ & -.103 & -.103 & -.105 & -.102 & -.100 & -.101 & -.046 \\
& $(.025)$ & $(.026)$ & $(.032)$ & $(.026)$ & $(.026)$ & $(.025)$ & $(.021)$ \\
$(03)(d, c)-(0, c)$ & .159 & .177 & .145 & .166 & .201 & .184 & .078 \\
& $(.057)$ & $(.062)$ & $(.089)$ & $(.061)$ & $(.076)$ & $(.065)$ & $(.037)$ \\
$(04)(0, c)-(d, c)$ & -.159 & -.177 & -.145 & -.166 & -.201 & -.184 & -.078 \\
& $(.057)$ & $(.062)$ & $(.089)$ & $(.061)$ & $(.076)$ & $(.065)$ & $(.037)$ \\
$(05)(d, 0)-(d, c)$ & -.018 & -.020 & -.025 & -.017 & -.017 & -.017 & -.001 \\
& $(.018)$ & $(.020)$ & $(.023)$ & $(.018)$ & $(.019)$ & $(.018)$ & $(.012)$ \\
$(06)(d, c)-(d, 0)$ & .018 & .020 & .025 & .017 & .017 & .017 & .001 \\
& $(.018)$ & $(.020)$ & $(.023)$ & $(.018)$ & $(.019)$ & $(.018)$ & $(.012)$ \\
$(07)(0,0)-(d, 0)$ & -.081 & -.063 & -.050 & -.080 & -.070 & -.076 & -.038 \\
& $(.036)$ & $(.042)$ & $(.049)$ & $(.036)$ & $(.040)$ & $(.037)$ & $(.028)$ \\
$(08)(d, 0)-(0,0)$ & .081 & .063 & .050 & .080 & .070 & .076 & .038 \\
& $(.036)$ & $(.042)$ & $(.049)$ & $(.036)$ & $(.040)$ & $(.037)$ & $(.028)$ \\
$(09)(0,0)-(0, c)$ & -.009 & -.006 & -.043 & -.011 & -.006 & -.012 & -.054 \\
& $(.055)$ & $(.068)$ & $(.078)$ & $(.054)$ & $(.064)$ & $(.057)$ & $(.046)$ \\
& .009 & .006 & .043 & .011 & .006 & .012 & .054 \\
$(10)(0, c)-(0,0)$ & $(.055)$ & $(.068)$ & $(.078)$ & $(.054)$ & $(.064)$ & $(.057)$ & $(.046)$ \\
& -.124 & -.141 & -.152 & -.125 & -.131 & -.126 & -.028 \\
$(11)(0, c)-(d, 0)$ & $(.050)$ & $(.058)$ & $(.066)$ & $(.051)$ & $(.053)$ & $(.051)$ & $(.035)$ \\
& .124 & .141 & .152 & .125 & .131 & .126 & .028 \\
$(12)(d, 0)-(0, c)$ & $(.050)$ & $(.058)$ & $(.066)$ & $(.051)$ & $(.053)$ & $(.051)$ & $(.035)$ \\
\hline \hline
\end{tabular}

Source: Ifo Innovation Survey, 1994-2004.

$T$ denotes the treatment, $C$ the control group. Possible treatments are as follows: $(0,0)$ (the no treatment case), $(d, 0)$ (new product innovations only), $(0, c)$ (new process innovations only), and $(d, c)$ (both new product and new process innovations).

Column (1): Radius matching with $r=0.05$; Column (2): Radius matching with $r=0.005$; Column (3): Nearest neighbor matching; Column (4): Kernel matching, Epanechnikov kernel, bandwidth 0.06; Column (5): Kernel matching, Epanechnikov kernel, bandwidth 0.02; Column (6): Kernel matching, Gaussian kernel; Column (7): Radius matching, $r=0.05$, with control for past export status. 
Table 8: Multiple treatment efFeCts: ROBustness CheCKS FOR $\gamma$

\begin{tabular}{lrrrrrrr} 
& \multicolumn{1}{c}{$(1)$} & \multicolumn{1}{c}{$(2)$} & \multicolumn{1}{c}{$(3)$} & \multicolumn{1}{c}{$(4)$} & \multicolumn{1}{c}{$(5)$} & \multicolumn{1}{c}{$(6)$} & \multicolumn{1}{c}{$(7)$} \\
\hline$(01)(d, c)-(0,0)$ & .106 & .105 & .102 & .105 & .103 & .104 & .053 \\
& $(.024)$ & $(.025)$ & $(.030)$ & $(.025)$ & $(.025)$ & $(.025)$ & $(.020)$ \\
$(02)(0,0)-(d, c)$ & -.106 & -.105 & -.102 & -.105 & -.103 & -.104 & -.053 \\
& $(.024)$ & $(.025)$ & $(.030)$ & $(.025)$ & $(.025)$ & $(.025)$ & $(.020)$ \\
$(03)(d, c)-(0, c)$ & .140 & .156 & .126 & .142 & .164 & .151 & .036 \\
& $(.048)$ & $(.052)$ & $(.065)$ & $(.049)$ & $(.056)$ & $(.051)$ & $(.035)$ \\
$(04)(0, c)-(d, c)$ & -.140 & -.156 & -.126 & -.142 & -.164 & -.151 & -.036 \\
& $(.048)$ & $(.052)$ & $(.065)$ & $(.049)$ & $(.056)$ & $(.051)$ & $(.035)$ \\
$(05)(d, 0)-(d, c)$ & -.031 & -.042 & -.049 & -.030 & -.036 & -.032 & -.009 \\
& $(.028)$ & $(.031)$ & $(.038)$ & $(.029)$ & $(.030)$ & $(.028)$ & $(.023)$ \\
$(06)(d, c)-(d, 0)$ & .031 & .042 & .049 & .030 & .036 & .032 & .009 \\
& $(.028)$ & $(.031)$ & $(.038)$ & $(.029)$ & $(.030)$ & $(.028)$ & $(.023)$ \\
$(07)(0,0)-(d, 0)$ & -.076 & -.063 & -.054 & -.075 & -.067 & -.072 & -.044 \\
& $(.028)$ & $(.032)$ & $(.035)$ & $(.028)$ & $(.030)$ & $(.028)$ & $(.021)$ \\
$(08)(d, 0)-(0,0)$ & .076 & .063 & .054 & .075 & .067 & .072 & .044 \\
& $(.028)$ & $(.032)$ & $(.035)$ & $(.028)$ & $(.030)$ & $(.028)$ & $(.021)$ \\
$(09)(0,0)-(0, c)$ & .034 & .051 & .023 & .037 & .061 & .047 & -.016 \\
& $(.049)$ & $(.053)$ & $(.065)$ & $(.049)$ & $(.056)$ & $(.052)$ & $(.033)$ \\
& -.034 & -.051 & -.023 & -.037 & -.061 & -.047 & .016 \\
$(10)(0, c)-(0,0)$ & $(.049)$ & $(.053)$ & $(.065)$ & $(.049)$ & $(.056)$ & $(.052)$ & $(.033)$ \\
& -.110 & -.114 & -.077 & -.112 & -.128 & -.119 & -.027 \\
$(11)(0, c)-(d, 0)$ & $(.050)$ & $(.055)$ & $(.069)$ & $(.052)$ & $(.058)$ & $(.054)$ & $(.035)$ \\
$(12)(d, 0)-(0, c)$ & .110 & .114 & .077 & .112 & .128 & .119 & .027 \\
& $(.050)$ & $(.055)$ & $(.069)$ & $(.052)$ & $(.058)$ & $(.054)$ & $(.035)$ \\
\hline \hline
\end{tabular}

Source: Ifo Innovation Survey, 1994-2004.

$T$ denotes the treatment, $C$ the control group. Possible treatments are as follows: $(0,0)$ (the no treatment case), $(d, 0)$ (new product innovations only), $(0, c)$ (new process innovations only), and $(d, c)$ (both new product and new process innovations).

Column (1): Radius matching with $r=0.05$; Column (2): Radius matching with $r=0.005$; Column (3): Nearest neighbor matching; Column (4): Kernel matching, Epanechnikov kernel, bandwidth 0.06; Column (5): Kernel matching, Epanechnikov kernel, bandwidth 0.02; Column (6): Kernel matching, Gaussian kernel; Column (7): Radius matching, $r=0.05$, with control for past export status. 
Similar conclusions apply for the estimates in Tables 7 and 8. Overall, neither the functional form of the multiple choice model, nor the alternative values for the radius, the type of the matching estimator (radius versus nearest-neighbor versus kernel), nor the kernel bandwidths or the functional forms of the kernels have a qualitative impact on the significant findings in the original table. Again, the impact of innovations is quantitatively smaller if we use lagged export status as a determinant of contemporaneous innovation mode in the selection models. However, most of the originally significant estimates remain significant even in this case and none of the 24 estimated point estimate signs in column (7) of Tables 7 and 8 is different from those in the other columns of the same tables.

In general, this paper's analysis provides robust evidence that product innovation is more important than process innovation for a firm's export propensity. However, while process innovation seems of little relevance for export propensity, it improves a firm's probability to export if it is accompanied by product innovation.

\section{Conclusions}

Our goal in this paper was to provide novel empirical insights in the role of product versus process innovation on export propensity at the firm level. Either of these modes of innovation has been hypothesized to affect firm-level productivity in previous theoretical work. A smaller body of theoretical research even pointed to the differential impact of these two types of innovation on a firm's export propensity. We aim at assessing the latter relationship empirically. Economic theory suggests that firms do not undertake innovations at random, neither product nor process innovations. Hence, empirical work should pay attention to the likely self-selection of firms into innovations. Viewing innovations as a 'treatment', this lends support to an endogenous treatment approach to innovations and export propensity. With two modes of innovations - product and process innovations -, one is then faced with an econometric framework with multiple endogenous treatments.

Adopting a so-called matching approach based on the propensity score and using survey data of German firms available from the Ifo Institute, we find that there is significant bias of the impact of product and process innovations on export propensity when ignoring self-selection into either mode of innovation. This bias was quite substantial in our application, having been 
particularly large for firms with only product or process innovations as compared to ones that did not innovate. The largest estimated self-selection bias in the data amounted to more than 200 percent, depending on the mode of innovations (product and/or process innovation).

Overall, the results point to the importance of product innovation relative to process innovation. In comparison, there is no evidence that process innovation fosters a firm's propensity to export beyond product innovation. This can be viewed as evidence on the importance of the extensive margin in product space for a firm's entry into export markets, lending support to new trade and endogenous growth theories with their emphasis on product innovations. 
Abadie, A. and G.W. Imbens, (2006) On the Failure of the Bootstrap for Matching Estimators, NBER Working Paper No. T0325.

Angrist, J.D. (1998), Estimating Labor Market Impact of Voluntary Military Service Using Social Security Data, Econometrica 66, 249-288.

Baily, M.N. and H. Gersbach (1995), Efficiency in Manufacturing and the Need for Global Competition, Brookings Papers on Economic Activity: Microeconomics, 307-358.

Basile, R. (2001), Export Behavior of Italian Manufacturing Firms Over the Nineties: The Role of Innovation, Research Policy 30, 1185-1201.

Bernard, A. and J.B. Jensen (1999), Exceptional Export Performance: Cause, Effect, or Both?, Journal of International Economics 47, 1-25.

Braunerhjelm, P. (1996), The Relation Between Firm Specific Intangibles and Exports, Economics Letters 53, 213-219.

Cassiman, B. and Martínez-Ros (2004), Innovation and Exports: Evidence from Spanish Manufacturing, unpublished manuscript, IESE Business School.

Cohen, W.M. and S. Klepper (1996), Firm Size and the Nature of Innovation within Industries: The Case of Process and Product R\&D, Review of Economics and Statistics 78, 232-243.

Davidson and MacKinnon (2004), Econometric Theory and Methods, Oxford University Press, New York.

Dehejia, R.H. and S. Wahba (1999), Causal Effects in Non-Experimental Studies: Reevaluating the Evaluation of Training Programmes, Journal of the American Statistical Association 94, 1053-1062.

Dehejia, R. H. and S. Wahba (2002), Propensity score matching methods for non-experimental causal studies, Review of Economics and Statistics 84, $151-161$.

Foellmi, R. and J. Zweimüller (2005), Mass Consumption, Exclusion, and Technological Unemployment, unpublished manuscript, University of Zurich.

Frölich, M. (2004), Programme Evaluation with Multiple Treatments, Journal of Economic Surveys 18, 181-224. 
Grossman, G.M. and E. Helpman (1989), Product Development and International Trade, Journal of Political Economy 97, 1261-83.

Grossman, G.M. and E. Helpman (1990), Comparative Advantage and Longrun Growth, American Economic Review 80, 796-815.

Heckman, J.J., H. Ichimura, and P. Todd (1997), Matching as an Econometric Evaluation Estimator: Evidence from a Job Training Programme, Review of Economic Studies 64, 605-654.

Heckman, J.J., H. Ichimura, and P. Todd (1998), Matching as an Econometric Evaluation Estimator, Review of Economic Studies 65, 261-294.

Heckman, J.J., R.J. LaLonde, and J.A. Smith (1999), The Economics and Econometrics of Active Labor Market Programs, in O. Ashenfelter and D. Card (eds.), Handbook of Labor Economics, Vol. III, 1865-2073.

Hirsch, S. and I. Bijaoui (1985), R\&D Intensity and Export Performance: A Micro View, Weltwirtschaftliches Archiv 121, 138-151.

Hughes, K.S. (1986), Exports and Innovation, European Economic Review 30, 383-399.

Imbens, G. (2000), The Role of the Propensity Score in Estimating DoseResponse Functions, Biometrika. 87(3), 706-710.

Jensen, R. and M. Thursby (1987), A Decision Theoretic Model of Innovation, Technology Transfer, and Trade, Review of Economic Studies 54, 631-647.

Kumar, N. and N.S. Siddharthan (1994), Technology, Firm Size and Export Behavior in Developing Countries: The Case of Indian Enterprise, Journal of Development Studies 32, 288-309.

Lachenmaier, S. and L. Wößmann (2006), Does Innovation Cause Exports? Evidence from Exogenous Innovation Impulses and Obstacles Using German Micro Data, Oxford Economic Papers 58(2), 317-350.

Leamer, E.E. and J. Levinsohn (1995), International Trade Theory: The Evidence, in: G.M. Grossman and K. Rogoff (eds.), The Handbook of International Economics, vol. III, Elsevier, 1339-1394. 
Lechner, M. (2001), Identification and Estimation of Causal Effects of Multiple Treatments Under the Conditional Independence Assumption, in: M. Lechner and F. Pfeiffer (eds.), Econometric Evaluation of Labor Market Policies, ZEW Economic Studies, vol. 13, 43-58.

Lee, M.-J. (2005), Micro-Econometrics for Policy, Program and Treatment Effects, Oxford: Oxford University Press.

Martin, S. (1983), Endogenous Firm Efficiency in a Cournot Principal-Agent Model, RAND Journal of Economics 59, 445-450.

Politis, D. N., J. P. Romano and M. Wolf (1999), Subsampling, Springer, New York.

Roper, S. and J.H. Love (2002), Innovation and Export Performance: Evidence from the UK and German Manufacturing Plants, Research Policy 31, 1087-1102.

Rosenbaum, P. R. and D. B. Rubin (1985), Constructing a Control Group Using Multivariate Matched Sampling Methods That Incorporate the Propensity Score, The American Statistician 39, 33-38.

Segerstrom, P.S., T.C.A. Anant, and E. Dinopoulos (1990), A Schumpeterian Model of the Product Life Cycle, American Economic Review 80, 1077-91.

Smith, J.A. and P.E. Todd (2005), Does Matching Overcome Lalonde's Critique of Nonexperimental Estimators, Journal of Econometrics 125, 305353.

Wakelin, K. (1998), Innovation and Export Behaviour at the Firm Level, Research Policy 26, 829-41.

Wooldridge, J.M. (2002), Econometric Analysis of Cross-section and Panel Data, Cambridge, MA: MIT Press.

\section{Appendix}

Table 9 summarizes the results of the bivariate probit model for the two choice indicators, product and process innovation. In contrast to the multinomial logit model in Table 3, it assumes a bivariate normal cumulative density function of the latent outcome variable. 
Table 9: Product And Process innovations: Bivariate Probit Product innovation Process innovation

(1)

(2)

Firm-level variables

$\ln$ (Turnover) in $t-1$

.352

.346

(.017)

(.016)

$\ln$ (Turnover per worker) in $t-1$

$-.258$

$-.238$

(.028)

(.027)

Indic.: Lacking own capital

.429

.400

(.079)

(.074)

Indic.: Lacking external capital

$-.058$

(.087)

$-.223$

(.081)

Indic.: Long amortization period

.821

(.057)

.628

(.052)

Indic.: Imperfect cooperation poss.

.230

.306

(.073)

(.067)

Sector-level variables

for Germany

$\ln$ (Value-added) in $t-1 \quad .326$

.114

(.074)

(.071)

$\ln$ (Value-added per worker) in $t-1$

$-.640$

$-.428$

(.161)

(.155)

$\ln ($ Unit labor cost) in $t-1$

1.638

.971

(.269)

(.258)

for EU14

$\ln$ (Value-added) in $t-1$

$-.325$

(.098)

$-.047$

(.093)

$\ln$ (Value-added per worker) in $t-1$

$-.026$

.046

(.122)

(.120)

$\ln$ (Unit labor cost) in $t-1$

$-1.762$

$-.824$

(.232)

(.224)

Constant

$-5.810$

$-4.619$

(.593)

(.566)

at $\rho$

.899

(.034)

Number of observations

4499

Source: Ifo Innovation Survey, 1994-2004.

28 


\section{CESifo Working Paper Series}

(for full list see www.cesifo-group.de)

1844 Eytan Sheshinski, Differentiated Annuities in a Pooling Equilibrium, November 2006

1845 Marc Suhrcke and Dieter Urban, Are Cardiovascular Diseases Bad for Economic Growth?, November 2006

1846 Sam Bucovetsky and Andreas Haufler, Preferential Tax Regimes with Asymmetric Countries, November 2006

1847 Luca Anderlini, Leonardo Felli and Andrew Postlewaite, Should Courts always Enforce what Contracting Parties Write?, November 2006

1848 Katharina Sailer, Searching the eBay Marketplace, November 2006

1849 Paul De Grauwe and Pablo Rovira Kaltwasser, A Behavioral Finance Model of the Exchange Rate with Many Forecasting Rules, November 2006

1850 Doina Maria Radulescu and Michael Stimmelmayr, ACE vs. CBIT: Which is Better for Investment and Welfare?, November 2006

1851 Guglielmo Maria Caporale and Mario Cerrato, Black Market and Official Exchange Rates: Long-Run Equilibrium and Short-Run Dynamics, November 2006

1852 Luca Anderlini, Leonardo Felli and Andrew Postlewaite, Active Courts and Menu Contracts, November 2006

1853 Andreas Haufler, Alexander Klemm and Guttorm Schjelderup, Economic Integration and Redistributive Taxation: A Simple Model with Ambiguous Results, November 2006

1854 S. Brock Blomberg, Thomas DeLeire and Gregory D. Hess, The (After) Life-Cycle Theory of Religious Contributions, November 2006

1855 Albert Solé-Ollé and Pilar Sorribas-Navarro, The Effects of Partisan Alignment on the Allocation of Intergovernmental Transfers. Differences-in-Differences Estimates for Spain, November 2006

1856 Biswa N. Bhattacharyay, Understanding the Latest Wave and Future Shape of Regional Trade and Cooperation Agreements in Asia, November 2006

1857 Matz Dahlberg, Eva Mörk, Jørn Rattsø and Hanna Ågren, Using a Discontinuous Grant to Identify the Effect of Grants on Local Taxes and Spending, November 2006

1858 Ernesto Crivelli and Klaas Staal, Size and Soft Budget Constraints, November 2006 
1859 Jens Brøchner, Jesper Jensen, Patrik Svensson and Peter Birch Sørensen, The Dilemmas of Tax Coordination in the Enlarged European Union, November 2006

1860 Marcel Gérard, Reforming the Taxation of Multijurisdictional Enterprises in Europe, "Coopetition" in a Bottom-up Federation, November 2006

1861 Frank Blasch and Alfons J. Weichenrieder, When Taxation Changes the Course of the Year - Fiscal Year Adjustments and the German Tax Reform 2000/2001, November 2006

1862 Hans Jarle Kind, Tore Nilssen and Lars Sørgard, Competition for Viewers and Advertisers in a TV Oligopoly, November 2006

1863 Bart Cockx, Stéphane Robin and Christian Goebel, Income Support Policies for PartTime Workers: A Stepping-Stone to Regular Jobs? An Application to Young LongTerm Unemployed Women in Belgium, December 2006

1864 Sascha O. Becker and Marc-Andreas Muendler, The Effect of FDI on Job Separation, December 2006

1865 Christos Kotsogiannis and Robert Schwager, Fiscal Equalization and Yardstick Competition, December 2006

1866 Mikael Carlsson, Stefan Eriksson and Nils Gottfries, Testing Theories of Job Creation: Does Supply Create Its Own Demand?, December 2006

1867 Jacques H. Drèze, Charles Figuières and Jean Hindriks, Voluntary Matching Grants Can Forestall Social Dumping, December 2006

1868 Thomas Eichner and Marco Runkel, Corporate Income Taxation of Multinationals and Unemployment, December 2006

1869 Balázs Égert, Central Bank Interventions, Communication and Interest Rate Policy in Emerging European Economies, December 2006

1870 John Geweke, Joel Horowitz and M. Hashem Pesaran, Econometrics: A Bird's Eye View, December 2006

1871 Hans Jarle Kind, Marko Koethenbuerger and Guttorm Schjelderup, Taxation in TwoSided Markets, December 2006

1872 Hans Gersbach and Bernhard Pachl, Cake Division by Majority Decision, December 2006

1873 Gunther Schnabl, The Evolution of the East Asian Currency Baskets - Still Undisclosed and Changing, December 2006

1874 Horst Raff and Michael J. Ryan, Firm-Specific Characteristics and the Timing of Foreign Direct Investment Projects, December 2006 
1875 Jukka Pirttilä and Håkan Selin, How Successful is the Dual Income Tax? Evidence from the Finnish Tax Reform of 1993, December 2006

1876 Agnieszka Stążka, Sources of Real Exchange Rate Fluctuations in Central and Eastern Europe - Temporary or Permanent?, December 2006

1877 Xavier Calsamiglia, Teresa Garcia-Milà and Therese J. McGuire, Why do Differences in the Degree of Fiscal Decentralization Endure?, December 2006

1878 Natacha Gilson, How to be Well Shod to Absorb Shocks? Shock Synchronization and Joining the Euro Zone, December 2006

1879 Scott Alan Carson, Modern Health Standards for Peoples of the Past: Biological Conditions by Race in the American South, 1873 - 1919, December 2006

1880 Peter Huber, Michael Pfaffermayr and Yvonne Wolfmayr, Are there Border Effects in the EU Wage Function?, December 2006

1881 Harry Flam and Håkan Nordström, Euro Effects on the Intensive and Extensive Margins of Trade, December 2006

1882 Panu Poutvaara and Mikael Priks, Hooliganism in the Shadow of the 9/11 Terrorist Attack and the Tsunami: Do Police Reduce Group Violence?, December 2006

1883 Ruud A. de Mooij and Gaëtan Nicodème, Corporate Tax Policy, Entrepreneurship and Incorporation in the EU, December 2006

1884 Johannes Becker and Clemens Fuest, Corporate Tax Policy and International Mergers and Acquisitions - Is the Tax Exemption System Superior?, January 2007

1885 Momi Dahan and Udi Nisan, The Effect of Benefits Level on Take-up Rates: Evidence from a Natural Experiment, January 2007

1886 José García-Solanes, Francisco I. Sancho-Portero and Fernando Torrejón-Flores, Beyond the Salassa-Samuelson Effect in some New Member States of the European Union, January 2007

1887 Peter Egger, Wolfgang Eggert and Hannes Winner, Saving Taxes Through Foreign Plant Ownership, January 2007

1888 Timothy J. Goodspeed and Andrew Haughwout, On the Optimal Design of Disaster Insurance in a Federation, January 2007

1889 Wim Groot, Henriëtte Maassen van den Brink and Bernard van Praag, The Compensating Income Variation of Social Capital, January 2007

1890 Bas Jacobs, Ruud A. de Mooij and Kees Folmer, Analyzing a Flat Income Tax in the Netherlands, January 2007 
1891 Hans Jarle Kind, Guttorm Schjelderup and Frank Stähler, Newspapers and Advertising: The Effects of Ad-Valorem Taxation under Duopoly, January 2007

1892 Erkki Koskela and Rune Stenbacka, Equilibrium Unemployment with Outsourcing under Labour Market Imperfections, January 2007

1893 Maarten Bosker, Steven Brakman, Harry Garretsen, Herman de Jong and Marc Schramm, The Development of Cities in Italy 1300 - 1861, January 2007

1894 Michel Beine, Oscar Bernal, Jean-Yves Gnabo and Christelle Lecourt, Intervention Policy of the BoJ: A Unified Approach, January 2007

1895 Robert S. Chirinko and Daniel J. Wilson, State Investment Tax Incentives: A Zero-Sum Game?, January 2007

1896 Theo S. Eicher and Oliver Roehn, Sources of the German Productivity Demise Tracing the Effects of Industry-Level ICT Investment, January 2007

1897 Helge Berger, Volker Nitsch and Tonny Lybek, Central Bank Boards around the World: Why does Membership Size Differ?, January 2007

1898 Gabriel Felbermayr and Wilhelm Kohler, Does WTO Membership Make a Difference at the Extensive Margin of World Trade?, January 2007

1899 Benno Torgler and Friedrich Schneider, The Impact of Tax Morale and Institutional Quality on the Shadow Economy, January 2007

1900 Tomer Blumkin and Efraim Sadka, On the Desirability of Taxing Charitable Contributions, January 2007

1901 Frederick van der Ploeg and Reinhilde Veugelers, Higher Education Reform and the Renewed Lisbon Strategy: Role of Member States and the European Commission, January 2007

1902 John Lewis, Hitting and Hoping? Meeting the Exchange Rate and Inflation Criteria during a Period of Nominal Convergence, January 2007

1903 Torben M. Andersen, The Scandinavian Model - Prospects and Challenges, January 2007

1904 Stephane Dees, Sean Holly, M. Hashem Pesaran and L. Vanessa Smith, Long Run Macroeconomic Relations in the Global Economy, January 2007

1905 Richard Jong-A-Pin and Jakob De Haan, Political Regime Change, Economic Reform and Growth Accelerations, January 2007

1906 Sascha O. Becker and Peter H. Egger, Endogenous Product versus Process Innovation and a Firm's Propensity to Export, February 2007 